\title{
Cytotoxic effects of mistletoe (Viscum album L.) in head and neck squamous cell carcinoma cell lines
}

\author{
Mª́ FÁTIMA G. KLINGBEIL ${ }^{1}$, FLÁVIA C.A. XAVIER ${ }^{2}$, LUIZ R. SARDINHA ${ }^{3}$, PATRICIA SEVERINO ${ }^{3}$, \\ MONICA B. MATHOR ${ }^{4}$, RODRIGO V. RODRIGUES ${ }^{5}$ and DÉCIO S. PINTO Jr ${ }^{1}$ \\ ${ }^{1}$ Department of Oral Pathology, School of Dentistry, University of São Paulo, 05508-000 São Paulo; ${ }^{2}$ Federal \\ University of Bahia, School of Dentistry Salvador, Canela, 40110-150 Bahia; ${ }^{3}$ Centro de Pesquisa Experimental do \\ Instituto Israelita de Ensino e Pesquisa Albert Einstein (IIEPAE), 0565-000 São Paulo; ${ }^{4}$ Radiation Technology Center \\ (CTR), Nuclear and Energetic Research Institute (IPEN-CNEN/SP), 05508-000 São Paulo; ${ }^{5}$ Department of Genetics \\ and Evolutionary Biology, Institute of Biosciences, University of São Paulo, 05508-090 São Paulo, Brazil
}

Received July 15, 2013; Accepted August 12, 2013

DOI: $10.3892 /$ or.2013.2732

\begin{abstract}
Head and neck squamous cell carcinoma is a complex disease with several etiologic factors and different molecular changes that may trigger certain events; it is also globally one of the most common malignancies in this topography. Extracts from Viscum album L. (VA) (mistletoe) have been used as adjuvant therapies with promising results in several types of cancer, mainly in European countries. In vitro studies have demonstrated that various types of VA may have cytotoxicity in carcinoma cells, activating the apoptotic cascade or leading cells to necrosis. This study aimed to verify the effects of three types of VA extracts (Iscador Qu Spezial, Iscador $\mathrm{P}$ and Iscador $\mathrm{M}$ ) in squamous cell carcinoma of the tongue cell lines SCC9 and SCC25, not previously studied. A concentration of $0.3 \mathrm{mg} / \mathrm{ml}\left(\mathrm{IC}_{50}\right)$ of the drugs induced apoptosis, affecting gene expression and protein levels of AKT, PTEN and CYCLIN D1. It was concluded that VA extracts have a cytotoxic effect on SCC9 and SCC25 cell lines, but while SCC9 cell line was more resistant to the action of the drugs, Iscador Qu Spezial and Iscador M have higher cytotoxic potential in both cell lines compared to Iscador P.
\end{abstract}

\section{Introduction}

Head and neck squamous cell carcinoma is the sixth most frequent neoplasm worldwide $(1,2)$. Even with advances in adjuvant therapies, survival rates have not improved significantly over the last 20 years (3). The major risk factors are

Correspondence to: Dr $\mathrm{M}^{\mathrm{a}}$ Fátima G. Klingbeil, Department of Oral Pathology, School of Dentistry, University of São Paulo, Av Lineu Prestes 2227, Cidade Universitária, 05508-000 São Paulo, Brazil

E-mail: fakling@usp.br

Key words: oral squamous cell carcinoma, Viscum album, Iscador, mistletoe, complementary therapy, antroposophic medicine, carcinogenesis, AKT, PTEN, CYCLIN D1 tobacco and alcohol (4), but some reports also suggest human papilloma virus infections (5). Surgical excision, radiotherapy or a combination of both are the treatments of choice $(6,7)$. Chemotherapy is occasionally used (6,7). Although a combination of treatments has proven efficient, the toxicity levels are high $(8,9)$.

Carcinogenesis is a multifactorial process involving several molecular events. Deregulation of cell cycle-related genes, such as $A K T, P T E N$ and CYCLINs, are common among these events. AKT is a serine/threonine kinase whose activation is highly correlated with several solid and hematologic types of cancer (10-12); PTEN acts at the G1 phase blocking the cell cycle that suppresses tumour progression (13-15). CYCLINs are also essential for the correct cell cycle transition $(16,17)$. These genes have been associated with head and neck squamous cell carcinomas.

Viscum album L. (VA), also called mistletoe, is a hemi-parasitic plant, originally found in Europe. Composed of the total plant extract, it implies a composition of great complexity (18) and is found to have a broad application in adjuvant therapy. Available clinical evidence supporting anticancer effects and in vitro studies using cancer cell lines have demonstrated cytotoxic effects that might trigger apoptotic signals (18-23). Over 200 host species are known, and it seems that distinct chemical properties of VA are associated with the host $(18,22)$. The main components of the plant extract presenting therapeutic application seem to be lectin, viscotoxins and polysaccharides (20).

Since there are no reports to date on the effect of this plant extract on oral squamous cell carcinomas, responses to different commercially available VA formulas were evaluated in cell lines derived from this cancer type. Results were assessed in terms of cell growth, apoptosis and expression of AKT, PTEN and CYCLIN D1.

\section{Materials and methods}

Cell lines and culture conditions. Human tongue cancer cell lines, purchased from the American Type Culture Collection 
(ATCC; Manassas, VA, USA) SCC9 (CRL-1629) and SCC25 (CRL-1628), were cultivated in Dulbecco's modified Eagle's medium and F-12 Nutrient Mixture (1:1) supplemented with $10 \%$ bovine serum product, penicillin $(100 \mathrm{U} / \mathrm{ml})$, streptomycin $(100 \mu \mathrm{g} / \mathrm{ml})$, amphotericin B $(2.5 \mu \mathrm{g} / \mathrm{ml})$ and glutamine $(4 \mathrm{mM})$ at $37^{\circ} \mathrm{C}$ in a humidified atmosphere containing $5 \%$ $\mathrm{CO}_{2}$. The cells were incubated for 24 and $48 \mathrm{~h}$ with the drugs at a concentration of $0.3 \mathrm{mg} / \mathrm{ml}$. This concentration corresponded to the $\mathrm{IC}_{50}$ and was determined by the MTS assay described below. These drugs were diluted in physiological solution and added to the cell culture. This mixture could not exceed $10 \%$ of the volume of the cell medium. Cytotoxicity of physiological solution was previously tested and presented no effect on cells (data not shown).

Drugs and reagents. The mistletoe extract Iscador is an aqueous sterile preparation derived from VA grown on oak (Quercus), apple tree (Mali) or pine (Pini), and fermented with Lactobacillus plantarum. Iscador Qu Spezial (Quercus) $5 \mathrm{mg}$, Iscador P (Pini) $10 \mathrm{mg}$ and Iscador M (Mali) $5 \mathrm{mg}$ from Weleda AG, Arlesheim, Switzerland. Western blotting and immunofluorescence were performed using anti-pAKT (sc7985; Santa Cruz Biotechnology, Inc., Dallas, TX, USA), anti-CYCLIN D1 (sc47698; Santa Cruz Biotechnology, Inc.), goat anti-rabbit (sc2004; Santa Cruz Biotechnology, Inc.), goat anti-mouse (sc2005; Santa Cruz Biotechnology, Inc.); anti-PTEN (ab23694; Abcam, Cambridge, MA, USA); mouse monoclonal anti- $\beta$-actin (clone AC-15; Sigma-Aldrich, St. Louis, MO, USA), and the secondary antibody conjugated with fluorescein (Novocastra). Mounting medium utilized for the immunofluorescence assay was VectaShield (Vector Laboratories).

$I C_{50}$ determination using MTS assay. Both cell lines were incubated in 96-well plates $\left(3 \times 10^{3} /\right.$ well $)$ in the presence of different concentrations of Iscador Qu Spezial. After 24, 48 and $72 \mathrm{~h}$ of cell culture, cell viability was assessed using a 3-(4,5-dimethylthiazol-2-yl)-5-(3-carboxymethoxyphenyl)2-(4-sulfophenyl)-2H-tetrazolium (MTS) assay kit (CellTiter 96 Aqueous One Solution; Promega) at an absorbance of $490 \mathrm{~nm}$ using a spectrophotometer. Considering that the amount of the active principle of Iscador Qu Spezial is the same as the Iscador $\mathrm{M}(5 \mathrm{mg} / \mathrm{ml})$, and half of the Iscador $\mathrm{P}(10 \mathrm{mg} / \mathrm{ml})$, $\mathrm{IC}_{50}$ obtained for Iscador Qu Spezial was used to adjust drug volumes accordingly at the time of the experiments.

Flow cytometric analysis of apoptosis. Apoptosis was assayed using an Annexin V-FITC/PI Apoptosis Detection kit (BD Pharmingen, Franklin Lakes, NJ, USA) following the manufacturer's protocol. The results were analysed using flow cytometry (BD FACSAria) with BD FACSDiva software, version 6.1.3.U, in order to distinguish viable, early apoptotic, late apoptotic or dead cells.

Relative quantification of gene expression using real-time PCR $(q P C R)$. The qPCR was performed to determine the expression level of genes: AKT1, AKT2, PTEN and CYCLIN D1. GAPDH was used as internal control. Primer sequences are shown in Table I. Total RNA was extracted from cell lines using TRIzol reagent (Invitrogen, Carlsbad, CA, USA). Samples of RNA
$(1.0 \mu \mathrm{g})$ were reverse transcribed with MultiScribe ${ }^{\mathrm{TM}}$ (High Capacity cDNA Archive kit; Applied Biosystems, Foster City, CA, USA), according to the manufacturer's protocol. qRT-PCR was carried out using SYBR-Green PCR Master mix (Applied Biosystems) for $10 \mathrm{~min}$ at $95^{\circ} \mathrm{C}$, followed by 40 cycles at $95^{\circ} \mathrm{C}$ for $10 \mathrm{sec}$ and $60^{\circ} \mathrm{C}$ for $1 \mathrm{~min}$. Dissociation curve analyses were performed at the end of cycling. Gene expression was calculated using a relative expression software tool (REST method, Pfaffl 2001).

Western blotting. Ten micrograms of protein were boiled (5 $\mathrm{min}$ ) and subjected to SDS-PAGE. Western blotting was performed according to a standard protocol using anti-human pAKT (1:700), PTEN (1:100) and CYCLIN D1 (1:75) followed by incubation with secondary antibody (goat anti-rabbit or goat anti-mouse, 1:3,000, respectively). Mouse monoclonal anti- $\beta$-actin $(1: 5,000)$ was the loading control. The bound antibodies were detected by colorimetric detection kit Opti-4CN.

Immunofluorescence assay. Cells in the cover slip were fixed with methanol, saturated in PBS/3\% bovine serum albumin and incubated $(1 \mathrm{~h})$ with anti-human pAKT (1:50), PTEN (1:50) and CYCLIN D1 (1:100). Afterwards, washing cells were incubated (45 min) with a secondary antibody (1:50) conjugated with fluorescein, at room temperature in a dark chamber. Three random visual fields (magnification, $\mathrm{x} 400$ ) were observed under a fluorescent microscope, Zeiss Axiophot II (Carl Zeiss, Oberkochen, Germany).

Statistical analysis. A Mann-Whitney test was used to determine the $\mathrm{IC}_{50}$ and in the apoptosis assay. The qRT-PCR analysed the drug effect over the gene expression after set time intervals. Data analyses were performed using Statistical Package for Social Sciences (SPSS), version 17.0. P-values $\leq 0.05$ were considered statistically significant.

\section{Results}

Iscador Qu Spezial induces cell death dose- and time-dependently. To determine whether the VA is capable of inducing cell death, both cell lines were treated with Iscador Qu Spezial for 24,48 and $72 \mathrm{~h}$ at various concentrations. The cell viability using MTS showed the time-dependent action of this drug. The determined $\mathrm{IC}_{50}$ was $0.3 \mathrm{mg} / \mathrm{ml}$ after $48 \mathrm{~h}$ of exposure $(\mathrm{P}=0.011)$ (Fig. 1). We then used the same concentration $(0.3 \mathrm{mg} / \mathrm{ml})$ for assays using Iscador $\mathrm{M}$ and Iscador P.

Iscador Qu Spezial and Iscador M are more efficient than Iscador P in inducing cell death in SCC9 and SCC25. To confirm the apoptotic effect of Iscador Qu Spezial, Iscador P and Iscador M in SCC9 and SCC25 cell lines, a flow cytometric assay was performed. Iscador Qu Spezial and Iscador M presented better apoptotic effect in both lineages after $48 \mathrm{~h}$, as compared to Iscador P (Fig. 2). The results also corroborate the time-dependent action of these drugs since we observed more apoptosis after $48 \mathrm{~h}$ than at $24 \mathrm{~h}$ of drug exposure.

$V A$ treatment alters the expression of AKT, PTEN and CYCLIN D1 in SCC 9 and SCC25. Real-time PCR was used in order to investigate the impact of the drugs on the relative 
Table I. Primer sequences.

Primers $\left(5^{\prime} \rightarrow 3^{\prime}\right)$

\begin{tabular}{llll}
\cline { 3 - 4 } Gene & Accession no. & \multicolumn{1}{c}{ Forward } & \multicolumn{1}{c}{ Reverse } \\
\hline AKT1 & NM 001014431.1 & TTTTTGAGCTCATCCTCATGG & ACACGATACCGGCAAAGAAG \\
AKT2 & NM 001626.3 & TGCCCTTCTACAACCAGGAC & AACCTGTGCTCCATGACCTC \\
$P T E N$ & NM 000314.4 & AGTGGCACTGTTGTTCACAAG & GTGTGGGTCCTGAATTGGAG \\
CYCLIN D1 & NM 53056.2 & CGTGGCCTCTAAGATGAAGG & CTGGCATTTTGGAGAGGAAG \\
GAPDH & NM 002046 & GCATCCTGGGCTACACTGA & CCACCACCCTGTTGCTGTA
\end{tabular}
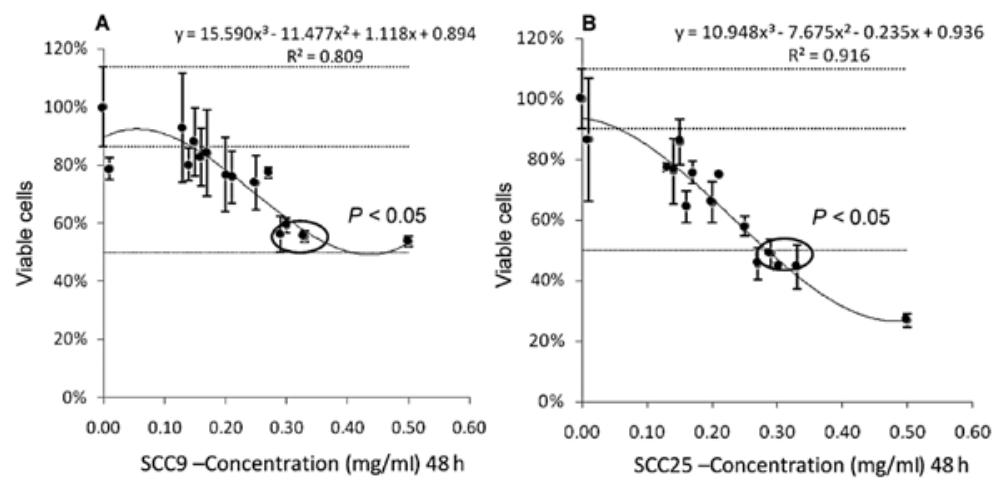

Figure 1. Viable cells (\%) after a 48-h incubation with Iscador Qu Spezial using MTS assay. (A) SCC9 and (B) SCC25 cells.
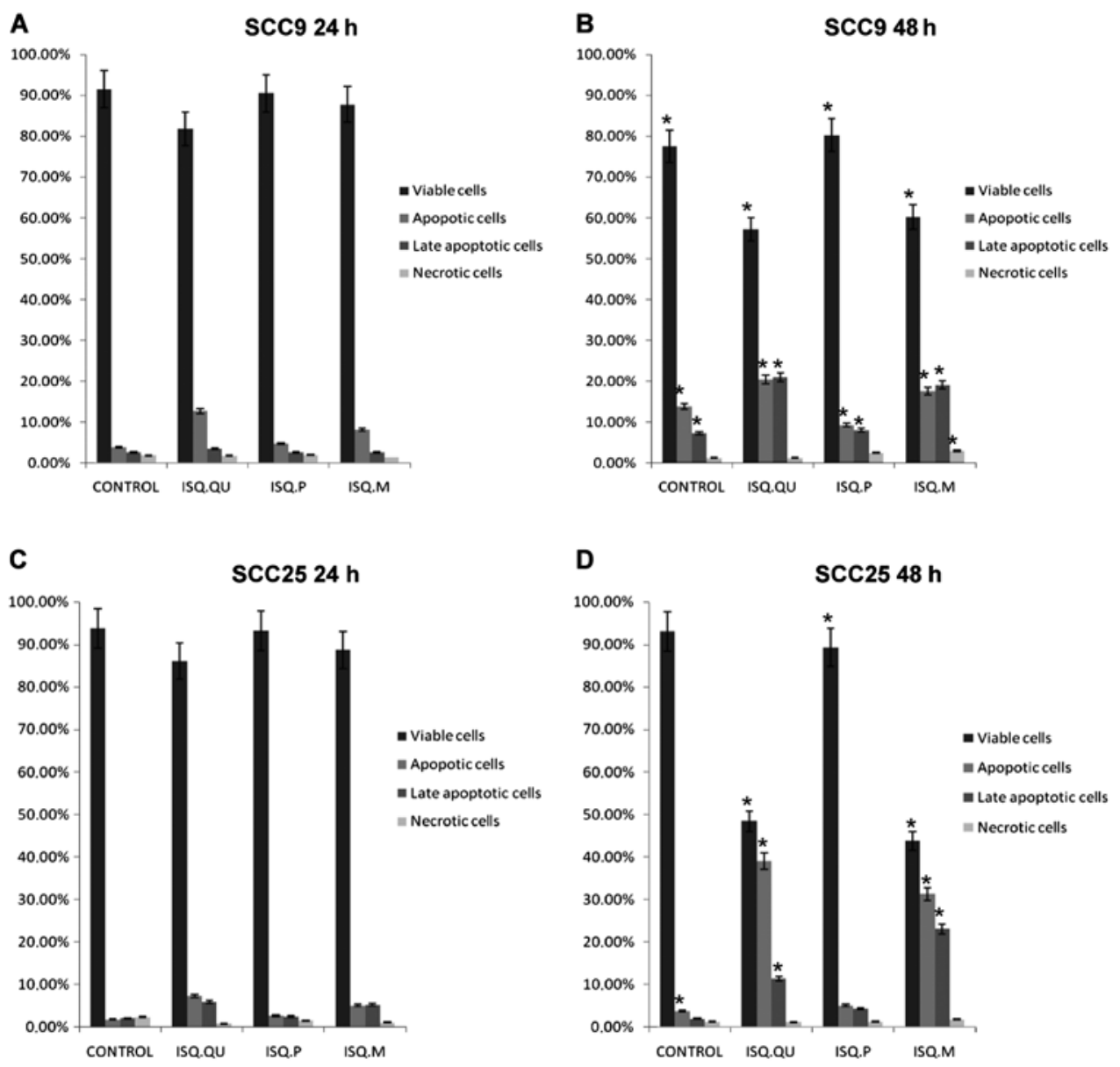

Figure 2. Viable, apoptotic, late apoptotic and necrotic cells after a 24- and 48-h incubation with the drugs. Annexin V-FITC/PI after flow cytometry analysis. ${ }^{*} \mathrm{P}<0.05$ compared both time 24 and $48 \mathrm{~h}$. (A and B) SCC9 24 and 48 h, respectively; (C and D) SCC25 24 and 48 h, respectively. 

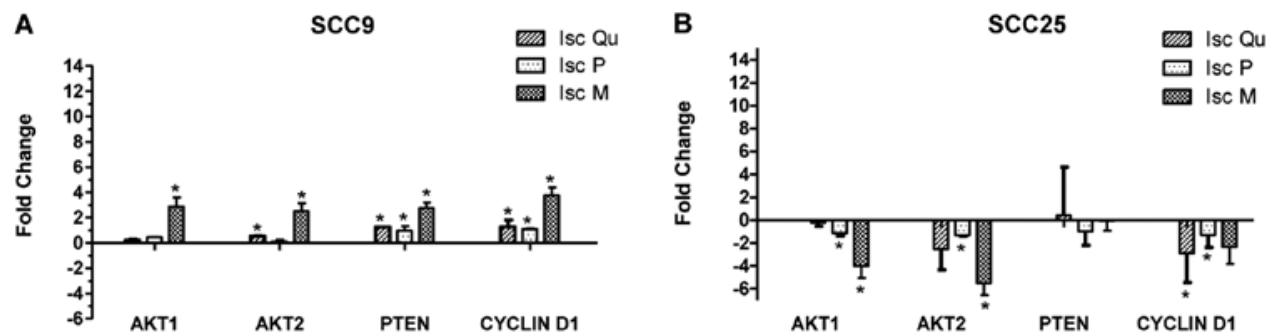

Figure 3. Fold-change of the expression of AKT1, AKT2, PTEN and CYCLIN D1 after incubation with Iscador Qu Spezial, P and M (24 and 28 h). (A) SCC9 and (B) SCC25 cells. ${ }^{*} \mathrm{P}<0.05$.

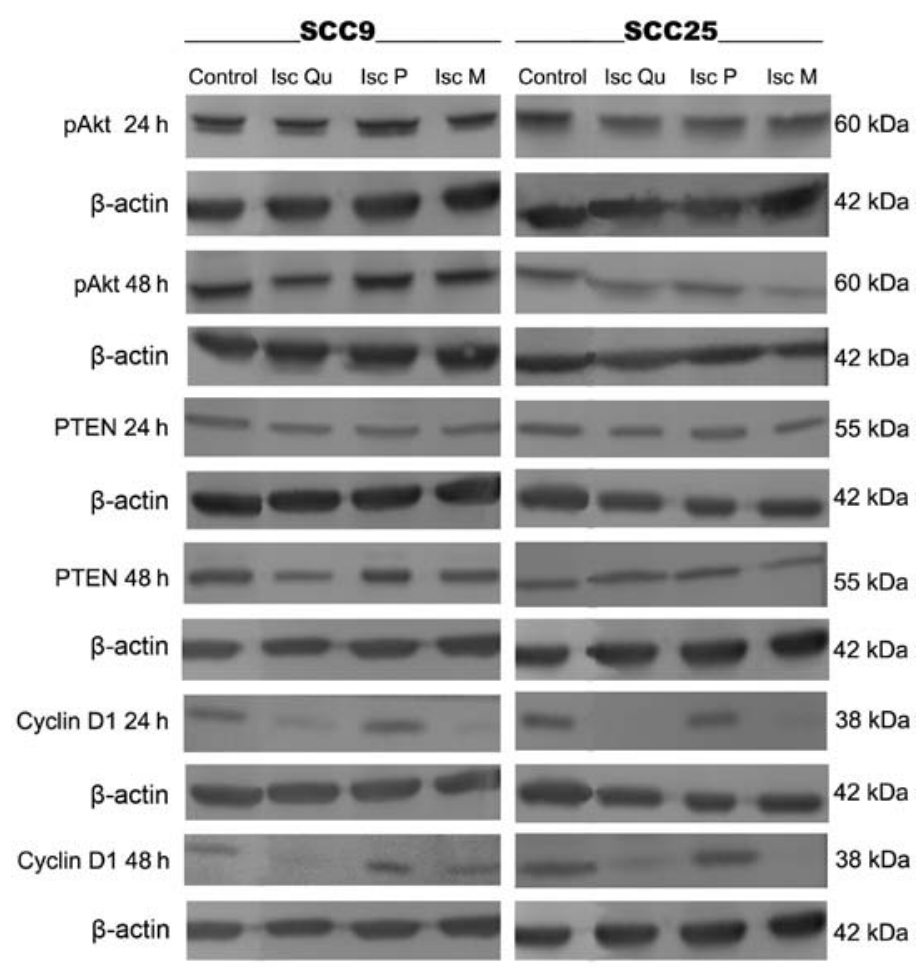

Figure 4. Western blot analyses showed pAkt, PTEN and CYCLIN D1 protein expression in SCC9 and SCC25 cell lines after 24 and $48 \mathrm{~h}$ of incubation with the drugs and control.

expression of AKT (AKT1, AKT2), PTEN and CYCLIN D1, after 24 and $48 \mathrm{~h}$ of treatment. The results were not uniform and varied depending on the cell line, drug and gene (Fig. 3).

Iscador Qu Spezial and Iscador M decreased the protein levels of CYCLIN D1 and PAKT. After $48 \mathrm{~h}$ of exposure to Iscador Qu and Iscador M, but not with Iscador P, the expression of pAKT showed a slight decrease in both cell lines (Fig. 4), while PTEN levels decreased only in SCC9, upon treatment with Iscador Qu Spezial. CYCLIN D1 protein levels did not vary when cells were treated with Iscador P whereas Iscador Qu Spezial and Iscador M treatment lead to a substantial decrease in the expression levels of CYCLIN D1 (Fig. 4).

The cell compartment localization of AKT, PTEN and CYCLIN DI changed after VA treatment. The localization of the proteins pAKT, PTEN and CYCLIN D1 in SCC9 and SCC25 cells upon VA treatment was assessed by immunofluorescence assay. pAKT expression in the nucleus was present in both cell lines regardless of the VA treatment (Fig. 5).
However, SCC9 cells treated with Iscador P and Iscador M for $48 \mathrm{~h}$ also showed a cytoplasmic pattern of staining. The presence of pAKT in the cytoplasm of SCC25 cells was seen only when they were treated with Iscador Qu Spezial (Fig. 5F, $\mathrm{J}$ and $\mathrm{N}$ ).

PTEN showed a predominantly nuclear pattern of staining after $24 \mathrm{~h}$ of treatment. At $48 \mathrm{~h}$, a cytoplasmic staining could be seen for both lineages at all instances, while nuclear staining disappeared for SCC9 control cells (Fig. 6B).

CYCLIN D1 location and pattern of expression was independent from the treatment or cell line at $24 \mathrm{~h}$. Cytoplasmic staining was seen after $48 \mathrm{~h}$ of treatment, except in SCC9 treated with Iscador Qu Spezial (Fig. 7E and F).

\section{Discussion}

In vitro action of mistletoe extract Iscador (Qu Spezial, Iscador $\mathrm{P}$ and Iscador $\mathrm{M}$ ) was evaluated on cells of tongue squamous cell carcinoma. The viability test showed a time-dependent action of the drug. In agreement, an ampoule 


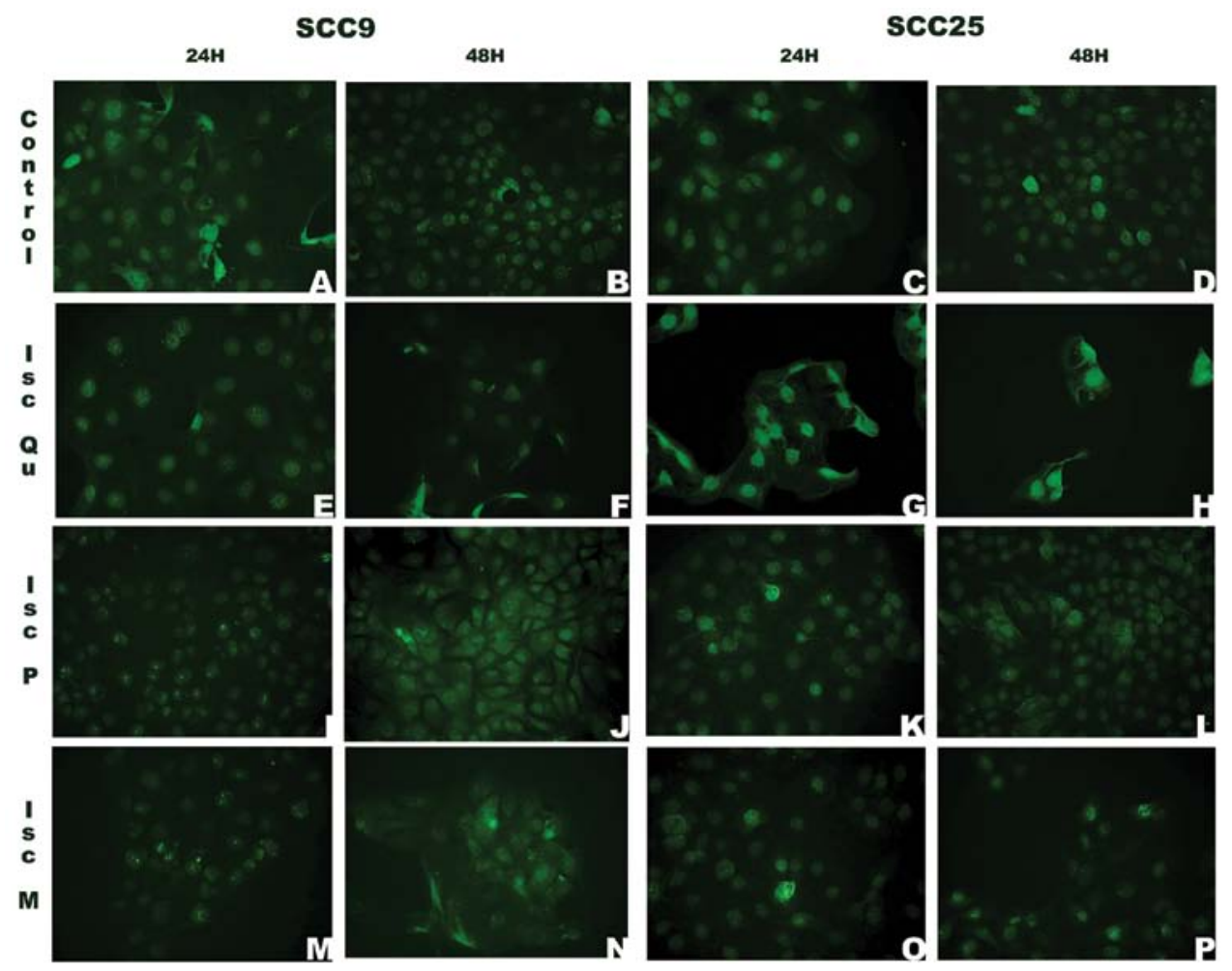

Figure 5. pAKT immunofluorescence assay after 24 and $48 \mathrm{~h}$ of incubation with the drugs and control in SCC9 and SCC25 cells. (A-D) Control; (E-H) Iscador Qu Spezial; (I-L) Iscador P; (M-P) Iscador M (magnification, x400).

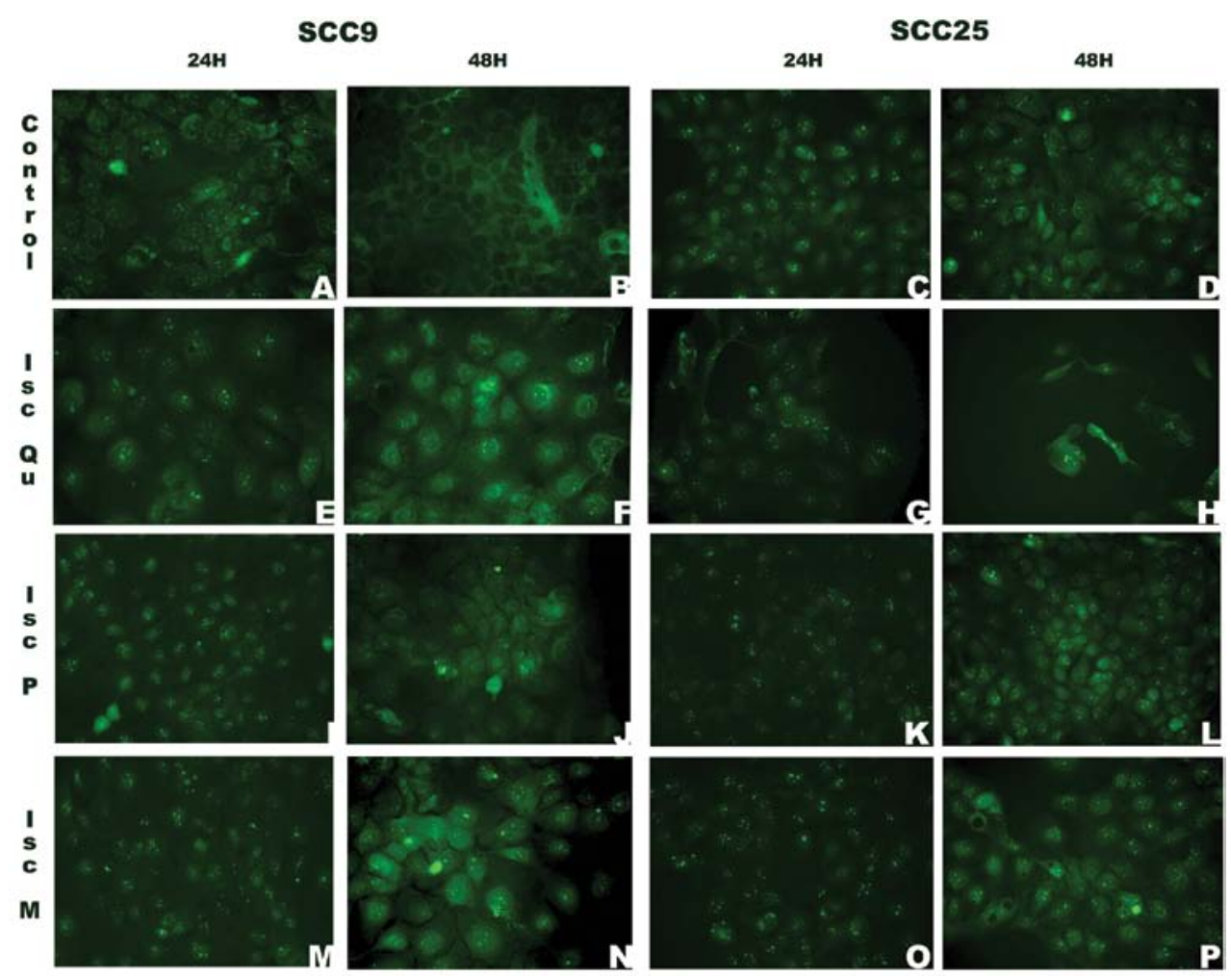

Figure 6. PTEN immunofluorescence assay after 24 and $48 \mathrm{~h}$ of incubation with the drugs and control in SCC9 and SCC25 cells. (A-D) Control; (E-H) Iscador Qu Spezial; (I-L) Iscador P; (M-P) Iscador M (magnification, x400).

of these drugs is used twice or three times a week in cancer treatment (24). The drug effect was different depending on the cell analysed, as previously observed by other authors $(18,19)$.
Eggenschwiler et al (22) observed that cell lines derived from the same type of tumor might have distinct behaviors in response to the same drug. In fact, SCC9 cells seem to 


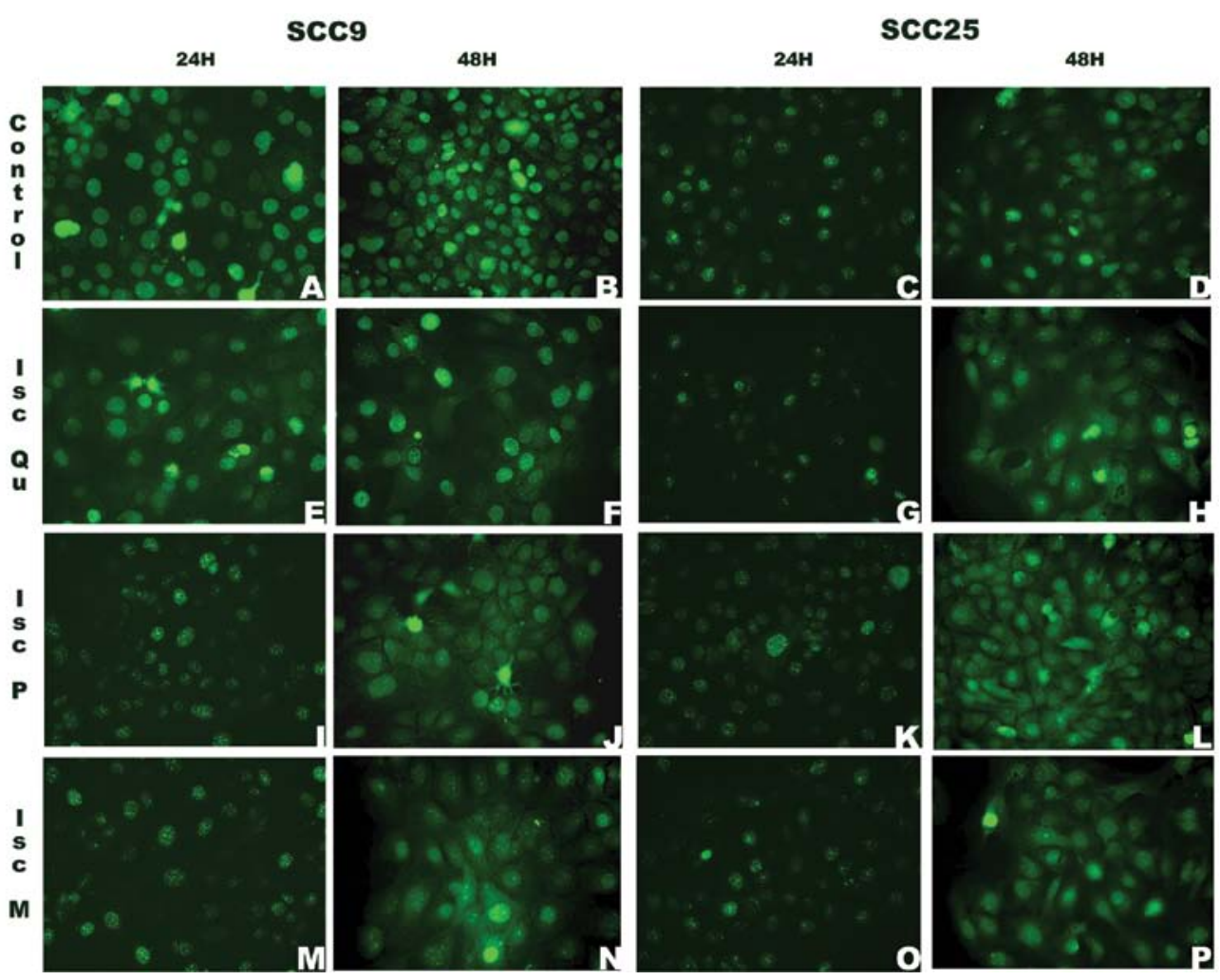

Figure 7. CYCLIN D1 immunofluorescence assay after 24 and $48 \mathrm{~h}$ of incubation with the drugs and control in SCC9 and SCC25 cells. (A-D) Control; (E-H) Iscador Qu Spezial; (I-L) Iscador P; (M-P) Iscador M (magnification, x400).

be more resistant to apoptosis induced by mistletoe when compared with SCC25. On the other hand, Iscador Qu Spezial, because of its higher concentration of viscotoxins and lectins, provided a stronger effect compared with the other extracts, as previously described $(18,20,22,23,25)$. We chose to analyse the effect of mistletoe on members of a pathway frequently deregulated in oral squamous cell carcinoma, AKT, PTEN and CYCLIN D1 $(15,26,27)$. Gene expression analysis by qRT-PCR of AKT1, AKT2, PTEN and CYCLIND1 was not consistent nor in agreement with their respective protein levels. These results suggest that mistletoe role on cell survival is not clearly related to the regulation of this pathway at the gene expression level.

Nevertheless, Iscador Qu Spezial and Iscador M decreased pAKT and CYCLIN D1 protein levels, leading to greater potential to cause cellular death as previously described $(18,22,23,25)$. The apoptosis triggered by the cytotoxic effects of these drugs may have been caused by inhibition of other signalling pathways also altered in cancers, such as EGFR/Ras/Raf/MEK/ERK (28). It may also have been triggered by the complex of STAT3 with NF- $\kappa \mathrm{B}$, which can lead to even more significant proliferative potential, through the expression of genes, such as c-myc and CYCLIN D1 (29). Studies of Sauter et al demonstrated that silencing of CYCLIN D1 also has an effect on inducing apoptosis in several cell lines of squamous cell carcinoma of the head and neck as well as skin and cervix (30). Baldin et al explain that CYCLIN D1 is detected in the nucleus during cell cycling; however, when cells enter the $\mathrm{S}$ phase, the expression increase in cytoplasm and decrease in nucleus (31). This could clarify the changes in cell locations observed in this study. Under normal conditions, CYCLIN D1 has nuclear localization in
G1 and is phosphorylated, ubiquitinized and transported to the cytoplasm in the $S$ phase $(29,31)$. The alteration of chromatin structure can explain the agglutinated aspect, which maintains the transcriptional repression of genes in $\mathrm{S}$ during early G1. These promoters are accessible only in the transition phase G1/S (31). pAKT acts directly on cell cycle progression, survival and proliferation $(28,32,33)$. The immunofluorescence analyses showed AKT at different cell locations. After AKT activation (pAKT) in the cytoplasm, it can be translocated to the nucleus. However, nuclear pAKT substrates have not been elucidated yet $(34,35)$. PTEN immunolocalization was detected after incubation with the drugs, although the quantitative analyses by western blotting were not able to demonstrate this positivity. Nuclear PTEN is involved with maintaining chromosome integrity and DNA repair $(36,37)$. A hypothetical action of the drugs analysed here could be the maintenance of nuclear PTEN, because it is protected from degradation by cytoplasmic proteasome. In the nucleus, it is still able to antagonize AKT and provoke apoptosis (37). A theory claims that translocation of PTEN from nucleus to cytoplasm may be associated with malignancy $(38,39)$. In the cytoplasm PTEN acts as a tumor suppressor by blocking PI3K (40).

This study highlights the fact that Iscador Qu Spezial and Iscador $\mathrm{M}$ are able to induce apoptosis in SCC9 and SCC25 cell lines, while Iscador $\mathrm{P}$ was less efficient in both lineages. Although the inhibition of CYCLIN D1 and pAKT were detected at the protein level, and a possible effect on protein location within the cell was detected, the nature of the cytotoxicity remains to be identified. SCC 9 cells seem to be more resistant to apoptosis induced by mistletoe when compared with SCC25 cells. Our results corroborate previously described 
effects of VA and suggest that it could be potentially used as a drug in OSCC therapy attempting to reverse a poor prognosis, leading to a better management of the disease.

\section{Acknowledgements}

The authors thank Dr Michael Werner of the Institut Hiscia Arlesheim (Switzerland) for providing all the ampoules of the three Iscador utilized in this study.

\section{References}

1. Jemal A, Tiwari RC, Murray T, Ghafoor A, Samuels A, Ward E, et al: Cancer statistics, 2004. CA Cancer J Clin 54: 8-29, 2004.

2. Warnakulasuriya S: Global epidemiology of oral and oropharyngeal cancer. Oral Oncol 45: 309-316, 2009.

3. Sklenicka S, Gardiner S, Dierks EJ, Potter BE and Bell RB Survival analysis and risk factors for recurrence in oral squamous cell carcinoma: does surgical salvage affect outcome? J Oral Maxillofac Surg 68: 1270-1275, 2010.

4. Tsantoulis PK, Kastrinakis NG, Tourvas AD, Laskaris G and Gorgoulis VG: Advances in the biology of oral cancer. Oral Oncol 43: 523-534, 2007.

5. Miller CS and Johnstone BM: Human papillomavirus as a risk factor for oral squamous cell carcinoma: a meta-analysis, 1982-1997. Oral Surg Oral Med Oral Pathol Oral Radiol Endod 91: 622-635, 2001

6. Scully C and Bagan J: Oral squamous cell carcinoma overview. Oral Oncol 45: 301-308, 2009.

7. Gold KA, Lee HY and Kim ES: Targeted therapies in squamous cell carcinoma of the head and neck. Cancer 115: 922-935, 2009

8. Corvò R: Evidence-based radiation oncology in head and neck squamous cell carcinoma. Radiother Oncol 85: 156-170, 2007.

9. Bernier J: Current state-of-the-art for concurrent chemoradiation. Semin Radiat Oncol 19: 3-10, 2009.

10. Bellacosa A, Kumar CC, Di Cristofano A and Testa JR: Activation of AKT kinases in cancer: implications for therapeutic targeting. Adv Cancer Res 94: 29-86, 2005.

11. Cicenas J: The potential role of Akt phosphorylation in human cancers. Int J Biol Markers 23: 1-9, 2008.

12. Molinolo AA, Amornphimoltham P, Squarize CH, Castilho RM, Patel V and Gutkind JS: Dysregulated molecular networks in head and neck carcinogenesis. Oral Oncol 45: 324-334, 2009

13. Okumura K, Mendoza M, Bachoo RM, DePinho RA, Cavenee WK and Furnari FB: PCAF modulates PTEN activity. J Biol Chem 281: 26562-26568, 2006.

14. Steck PA, Pershouse MA, Jasser SA, Yung WK, Lin H, Ligon AH, et al: Identification of a candidate tumour suppressor gene, MMAC1, at chromosome 10q23.3 that is mutated in multiple advanced cancers. Nat Genet 15: 356-362, 1997.

15. Kurasawa Y, Shiiba M, Nakamura M, Fushimi K, Ishigami T, Bukawa $\mathrm{H}$, et al: PTEN expression and methylation status in oral squamous cell carcinoma. Oncol Rep 19: 1429-1434, 2008.

16. Lundberg AS and Weinberg RA: Control of the cell cycle and apoptosis. Eur J Cancer 35: 531-539, 1999.

17. el-Naggar AK, Steck K and Batsakis JG: Heterogeneity of the proliferative fraction and cyclin D1/CCND1 gene amplification in head and neck squamous cell carcinoma. Cytometry 21: 47-51, 1995.

18. Zuzak TJ, Rist L, Eggenschwiler J, Grotzer MA and Viviani A: Paediatric medulloblastoma cells are susceptible to Viscum album (mistletoe) preparations. Anticancer Res 26: 3485-3492, 2006.

19. Harmsma M, Grommé M, Ummelen M, Dignef W, Tusenius KJ and Ramaekers FC: Differential effects of Viscum album extract Iscador $\mathrm{Qu}$ on cell cycle progression and apoptosis in cancer cells. Int J Oncol 25: 1521-1529, 2004.

20. Goedings P: Über die bildung von Viscum album L. Element der Naturwissenschaft 67: 1-23, 1997 (In German).
21. Molassiotis A, Scott JA, Kearney N, Pud D, Magri M, S, et al: Complementary and alternative medicine use in breast cancer patients in Europe. Support Care Cancer 14: 260-267, 2006.

22. Eggenschwiler J, Patrignani A, Wagner U, Rehrauer H, Schlapbach R, Rist L, et al: Gene expression profiles of different breast cancer cells compared with their responsiveness to fermented mistletoe (Viscum album L.) extracts Iscador from oak (Quercus), pine (Pinus), white fir (Abies) and apple tree (Malus) in vitro. Arzneimittelforschung 56: 483-496, 2006.

23. Urech K, Buessing A, Thalmann G, Schaefermeyer H and Heusser P: Antiproliferative effects of mistletoe (Viscum album L.) extract in urinary bladder carcinoma cell lines. Anticancer Res 26: 3049-3055, 2006.

24. Matthes H, Friedel WE, Bock PR and Zänker KS: Molecular mistletoe therapy: friend or foe in established anti-tumor protocols? A multicenter, controlled, retrospective pharmaco-epidemiological study in pancreas cancer. Curr Mol Med 10: 430-439, 2010.

25. Maier G and Fiebig HH: Absence of tumor growth stimulation in a panel of 16 human tumor cell lines by mistletoe extracts in vitro. Anticancer Drugs 13: 373-379, 2002.

26. Pedrero JM, Carracedo DG, Pinto CM, Zapatero AH, Rodrigo JP, Nieto CS, et al: Frequent genetic and biochemical alterations of the PI3K/Akt/PTEN pathway in head and neck squamous cell carcinoma. Int J Cancer 114: 242-248, 2005.

27. Cheng JQ, Ruggeri B, Klein WM, Sonoda G, Altomare DA, Watson DK and Testa JR: Amplification of Akt2 in human pancreatic cells and inhibition of Akt2 expression and tumorigenicity by antisense RNA. Proc Natl Acad Sci USA 93: 3636-3641, 1996.

28. Brazil DP, Yang ZZ and Hemmings BA: Advances in protein kinase B signalling: AKTion on multiple fronts. Trends Biochem Sci 29: 233-242, 2004

29. Diehl JA, Zindy F and Sherr CJ: Inhibition of cyclin D1 phosphorylation on threonine-286 prevents its rapid degradation via the ubiquitin-proteasome pathway. Genes Dev 11: 957-972, 1997.

30. Sauter ER, Nesbit M, Litwin S, Klein-Szanto AJ, Cheffetz S and Herlyn M: Antisense cyclin D1 induces apoptosis and tumor shrinkage in human squamous carcinoma. Cancer Res 59: 4876-4881, 1999.

31. Baldin V, Lukas J, Marcote MJ, Pagano M and Draetta G: Cyclin D1 is a nuclear protein required for cell cycle progression in G1. Genes Dev 7: 812-821, 1993.

32. Altomare DA and Testa JR: Perturbations of the AKT signaling pathway in human cancer. Oncogene 24: 7455-7464, 2005.

33. Vivanco I and Sawyers CL: The phosphatidylinositol 3-kinase AKT pathway in human cancer. Nat Rev Cancer 2: 489-501, 2002.

34. Andjelkovic M, Alessi DR, Meier R, Fernandez A, Lamb NJ, Frech M, et al: Role of translocation in the activation and function of protein kinase B. J Biol Chem 272: 31515-31524, 1997.

35. Nicholson KM and Anderson NG: The protein kinase B/Akt signaling pathway in human malignancy. Cell Signal 14: 381-395, 2002.

36. Shen WH, Balajee AS, Wang J, Wu H, Eng C, Pandolfi PP, et al: Essential role for nuclear PTEN in maintaining chromosomal integrity. Cell 128: 157-170, 2007.

37. Trotman LC, Wang X, Alimonti A, Chen Z, Teruya-Feldstein J, Yang H, et al: Ubiquitination regulates PTEN nuclear import and tumor suppression. Cell 128: 141-156, 2007.

38. Perren A, Komminoth P, Saremaslani P, Matter C, Feurer S, Lees JA, et al: Mutation and expression analyses reveal differential subcellular compartmentalization of PTEN in endocrine pancreatic tumors compared to normal islet cells. Am J Pathol 157: 1097-1103, 2000.

39. Gimm O, Perren A, Weng LP, Marsh DJ, Yeh JJ, Ziebold U, et al: Differential nuclear and cytoplasmic expression of PTEN in normal thyroid tissue, and benign and malignant epithelial thyroid tumors. Am J Pathol 156: 1693-1700, 2000.

40. Cully M, You H, Levine AJ and Mak TW: Beyond PTEN mutations: the PI3K pathway as an integrator of multiple inputs during tumorigenesis. Nat Rev Cancer 6: 184-192, 2006. 